\title{
Development of binary and ternary titanium alloys for dental implants
}

\author{
Jairo M. Cordeiro ${ }^{a, b}$, Thamara Beline ${ }^{a, b}$, Ana Lúcia R. Ribeiro ${ }^{c, d}$, \\ Elidiane C. Rangel ${ }^{e}$, Nilson C. da Cruz ${ }^{e}$, Richard Landers ${ }^{f}$, \\ Leonardo P. Faverani ${ }^{g}$, Luís Geraldo Vaz ${ }^{h}$, Laiza M.G. Fais ${ }^{h}$, \\ Fabio B. Vicente ${ }^{b, i}$, Carlos R. Grandini ${ }^{b, j}$, Mathew T. Mathew ${ }^{b, k, l}$, \\ Cortino Sukotjo ${ }^{b, l}$, Valentim A.R. Barão ${ }^{a, b, *}$
}

a University of Campinas (UNICAMP), Piracicaba Dental School, Department of Prosthodontics and Periodontology, Av. Limeira, 901, Piracicaba, São Paulo 13414-903, Brazil

${ }^{\mathrm{b}}$ Institute of Biomaterials, Tribocorrosion and Nanomedicine (IBTN), Brazil and USA

c Faculdade de Ciências do Tocantins (FACIT), Rua D 25, Qd 11, Lt 10, Setor George Yunes, Araguaína, Tocantins 77818-650, Brazil

d Faculdade de Ciências Humanas, Econômicas e da Saúde de Araguaína/Instituto Tocantinense Presidente Antônio Carlos (FAHESA/ITPAC), Av. Filadélfia, 568, Araguaína, Tocantins 77816-540, Brazil

e Univ Estadual Paulista (UNESP), Engineering College, Laboratory of Technological Plasmas, Av. Três de Março, 511, Sorocaba, São Paulo 18087-180, Brazil

${ }^{\mathrm{f}}$ University of Campinas (UNICAMP), Institute of Physics Gleb Wataghin, Cidade Universitária Zeferino

Vaz-Barão Geraldo, Campinas, São Paulo 13083-859, Brazil

g Univ Estadual Paulista (UNESP), Aracatuba Dental School, Department of Surgery and Integrated Clinic, R. José Bonifácio, 1193, Aracatuba, São Paulo 16015-050, Brazil

h Univ Estadual Paulista (UNESP), Araraquara Dental School, Department of Dental Materials and Prosthodontics, R. Humaitá, 1680, Araraquara, São Paulo 14801-903, Brazil

i Universidade Paulista (UNIP), Au. Nossa Sra. de Fátima, 9-50, Bauru, São Paulo 17017-337, Brazil

j Univ Estadual Paulista (UNESP), Laboratório de Anelasticidade e Biomateriais, Av. Eng. Luiz Edmundo Carrijo Coube, Bauru, São Paulo 17033-360, Brazil

${ }^{\mathrm{k}}$ University of Illinois College of Medicine at Rockford, Department of Biomedical Sciences, 1601 Parkview Avenue, Rockford, IL 61107, USA

${ }^{1}$ University of Illinois at Chicago, College of Dentistry, Department of Restorative Dentistry, 801 S Paulina, Chicago, IL 60612, USA

\section{A R T I C L E I N F O}

Article history:

Received 6 June 2017

Received in revised form

10 July 2017

Accepted 13 July 2017

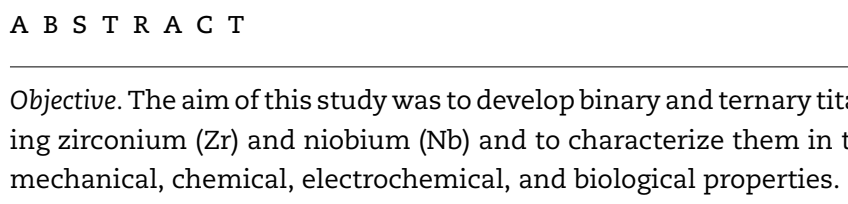
mechanical, chemical, electrochemical, and biological properties.

Objective. The aim of this study was to develop binary and ternary titanium (Ti) alloys containing zirconium $(\mathrm{Zr})$ and niobium $(\mathrm{Nb})$ and to characterize them in terms of microstructural,

Methods. The experimental alloys - (in wt\%) Ti-5Zr, Ti-10Zr, Ti-35Nb-5Zr, and Ti-35Nb-10Zr - were fabricated from pure metals. Commercially pure titanium (cpTi) and Ti-6Al-4V were used as controls. Microstructural analysis was performed by means of X-ray diffraction

\footnotetext{
* Corresponding author at: Av. Limeira, 901, Piracicaba, São Paulo 13414-903, Brazil. Fax: +55 1921065218

E-mail address: vbarao@unicamp.br (V.A.R. Barão).

http://dx.doi.org/10.1016/j.dental.2017.07.013

0109-5641/@ 2017 The Academy of Dental Materials. Published by Elsevier Ltd. All rights reserved.
} 
Keywords:

Alloys

Titanium

Zirconium

Dental implant

Corrosion and scanning electron microscopy. Vickers microhardness, elastic modulus, dispersive energy spectroscopy, X-ray excited photoelectron spectroscopy, atomic force microscopy, surface roughness, and surface free energy were evaluated. The electrochemical behavior analysis was conducted in a body fluid solution ( $\mathrm{pH}$ 7.4). The albumin adsorption was measured by the bicinchoninic acid method. Data were evaluated through one-way ANOVA and the Tukey test $(\alpha=0.05)$.

Results. The alloying elements proved to modify the alloy microstructure and to enhance the mechanical properties, improving the hardness and decreasing the elastic modulus of the binary and ternary alloys, respectively. Ti-Zr alloys displayed greater electrochemical stability relative to that of controls, presenting higher polarization resistance and lower capacitance. The experimental alloys were not detrimental to albumin adsorption.

Significance. The experimental alloys are suitable options for dental implant manufacturing, particularly the binary system, which showed a better combination of mechanical and electrochemical properties without the presence of toxic elements.

(c) 2017 The Academy of Dental Materials. Published by Elsevier Ltd. All rights reserved.

\section{Introduction}

Commercially pure titanium (cpTi) has been widely used as the main biomaterial for the manufacture of dental implants [1,2]. Nevertheless, like any other material used in physiological conditions, it is exposed to mechanical and biological factors [3] that may impair implant survival and long-term treatment success. In this context, alloys have been considered to be the treatment of choice [4], due to their improved properties, which allow for the development of materials according to clinical demands [5].

The Ti-6Al-4V alloy is widely used in the replacement of cpTi in situations where high strength is required [6] because of its excellent mechanical performance [2]. However, this material has been shown to be biomechanically incompatible owing to its higher elastic modulus compared with that of bone. Further, Ti-Al-V has been associated with the release of $\mathrm{V}$ into the blood and urine [7], initiation of the inflammatory cascade leading to osteolysis [8,9], neurotoxic effects, negative cell viability response, and, consequently, an undesirable outcome for implant biocompatibility with ion release [10-12]. In addition, Al has been shown to be present in brain tissue of patients with Alzheimer's disease [13].

Metal ions and debris released from implant materials are strongly associated with implant corrosion tendencies in physiological conditions [14,15]. Besides affecting the implant's biocompatibility, the corrosion phenomenon changes the implant's mechanical properties and affects the bone through the abrasion and wear regimes [16]. Thus, implant materials must not only fulfill mechanical requirements but also offer appropriate biological and electrochemical properties.

Experimental $\mathrm{Ti}$ alloys without the presence of $\mathrm{Al}$ and $\mathrm{V}$ are being processed and studied to achieve these properties [17]. Zirconium ( $\mathrm{Zr}$ ) and niobium (Nb) elements have attracted much special attention [18]. $\mathrm{Zr}$ acts as a solid-solution strengthening component when alloyed with $\mathrm{Ti}[1,19]$. Ti-Zr alloys present a predominantly $\alpha$-crystalline structure, which guarantees increased mechanical resistance and excellent electrochemical behavior $[1,20]$. In contrast, $\mathrm{Nb}$ is a $\beta$-stabilizer that is added to Ti to create $\alpha+\beta$ and $\beta$ alloys, which have demonstrated more promising properties for biomedical use [21], such as an excellent combination of low elastic modulus and high tensile strength [22,23]. In addition, the Ti-Nb-Zr alloy has shown non-toxicity toward osteoblastic cells, no allergy-related problems, and excellent biocompatibility [18].

To extend the clinical application of implants, it is necessary to develop new alloys that are sufficiently strong, present low elastic modulus, and are stable in a physiological environment. As mentioned above, $\mathrm{Ti}-\mathrm{Zr}$ and $\mathrm{Ti}-\mathrm{Nb}-\mathrm{Zr}$ alloys appear to be promising candidates for dental implant applications. Extensive studies have been conducted with cpTi and Ti-6Al-4 V [24-28], but studies with Ti alloys containing Nb and $\mathrm{Zr}$ are limited. Thus, the aim of the current study was to characterize the microstructure and mechanical, chemical, and electrochemical properties of binary and ternary $\mathrm{Ti}$ alloys containing $\mathrm{Zr}$ and $\mathrm{Nb}$ and to conduct a comparison with the materials that are widely used for dental implants: cpTi and Ti-6Al-4V alloy. The biological aspects of such alloys were investigated by means of a protein adsorption assay.

\section{Materials and methods}

The experimental design of this study can be seen in Fig. 1. Two control groups were considered: cpTi and Ti-6Al-4V alloy discs (Mac-Master Carr, Elmhurst, IL, USA) $10 \mathrm{~mm}$ in diameter and $2 \mathrm{~mm}$ in thickness. These materials were chosen because they are widely used in the manufacture of dental implants.

\subsection{Fabrication of experimental alloys}

The experimental alloys (in wt\%) (Ti-5Zr, Ti-10Zr, Ti-35Nb-5Zr, and $\mathrm{Ti}-35 \mathrm{Nb}-10 \mathrm{Zr}$ ) were melted from pure metals ( $\mathrm{Ti}, \mathrm{Nb}$, and $\mathrm{Zr}$ presented degrees of purity equal or superior to $99.0 \%$ ) (Sigma-Aldrich, St. Louis, MO, USA) in an arc-voltaic furnace with a water-cooled copper crucible under an argon atmosphere. The ingots were flipped and re-melted five times to ensure homogeneity of the samples $[1,29,30]$. The Ti-Nb-Zr ingots were encapsulated in quartz tubes, heat-treated at $1000^{\circ} \mathrm{C}$ for $8 \mathrm{~h}$, and furnace-cooled $[29,30]$. All ingots were 


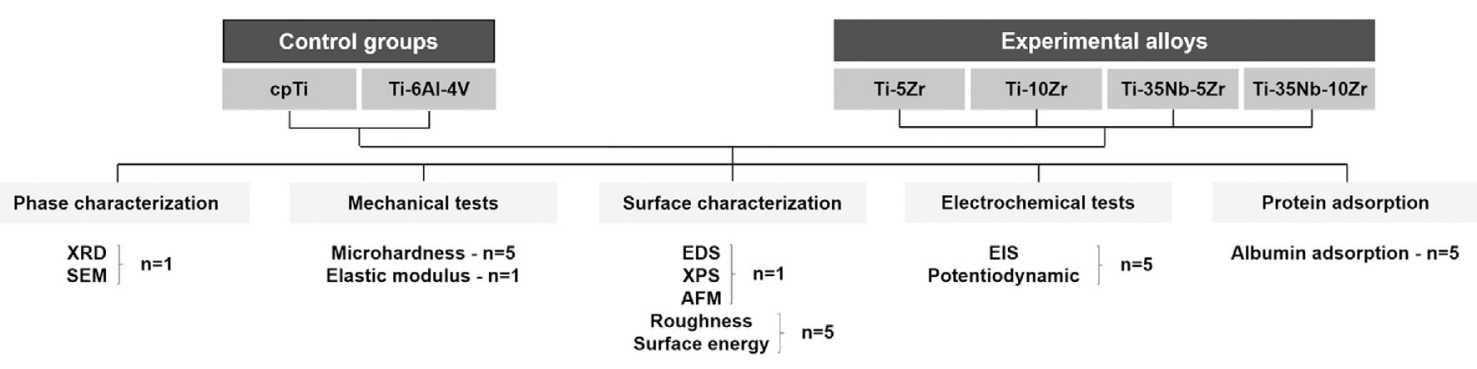

Fig. 1 - Schematic diagram of the experimental design.

heated to $1000^{\circ} \mathrm{C}$ and hot-swaged to form bars $\approx 11 \mathrm{~mm}$ in diameter. Then, Ti-Nb-Zr was machined into discs $(10 \mathrm{~mm}$ in diameter and $2 \mathrm{~mm}$ in thickness). After that, the $\mathrm{Ti}-\mathrm{Nb}-\mathrm{Zr}$ discs and the Ti-Zr ingots were heat-treated at $1000^{\circ} \mathrm{C}$ for $1 \mathrm{~h}$ and air-cooled to improve the alloys' mechanical behavior and to relieve tensions generated during the machining procedure [30]. Ti-Zr ingots were also machined into discs with the abovementioned dimensions.

All discs were polished with \#320-, \#400-, and \#600-grit SiC abrasive papers (Carbimet 2, Buehler, Lake Bluff, IL, USA) in an automatic polisher (EcoMet 300 Pro with AutoMet 250; Buehler, Lake Bluff, IL, USA) for surface standardization. Then, samples were ultrasonically cleaned with deionized water $(10 \mathrm{~min})$ and 70\% propanol (10 min) (Sigma-Aldrich, St. Louis, MO, USA) and dried with warm air [24].

\subsection{Phase characterization}

The microstructural phases of the alloys were determined by X-ray diffractometry (XRD). A diffractometer (XRD; Panalytical, X'Pert3 Powder, Almelo, The Netherlands) was used, with $\mathrm{Cu}-\mathrm{K} \alpha(\lambda=1.540598 \AA)$ radiation and operating at $45 \mathrm{kV}$ and $40 \mathrm{~mA}$ at a continuous speed of $0.02^{\circ}$ per second and a scan range from $20^{\circ}$ to $90^{\circ}$. The microstructural analysis of the alloys was confirmed by scanning electron microscopy (SEM; JEOL JSM-6010LA, Peabody, MA, USA). For that, the samples were conventionally polished as described above and then polished to a mirror finish with diamond paste (MetaDi 9micron, Buehler, Lake Bluff, IL, USA), a polishing cloth (TextMet Polishing Cloth, Buehler, Lake Bluff, IL, USA), and lubricant (MetaDi Fluid, Buehler, Lake Bluff, IL, USA). Finally, a colloidal silica polishing suspension (MasterMed, Buehler, Lake Bluff, IL, USA) was used together with a ChemoMet I polishing cloth (Buehler, Lake Bluff, IL, USA) [24]. The samples were subsequently etched for $4-5 \mathrm{~s}$ with Kroll's reagent (5\% nitric acid, 10\% hydrofluoric acid, and $85 \%$ water) (Sigma-Aldrich, St. Louis, MO, USA) [31].

\subsection{Mechanical properties}

The Vickers hardness was measured by means of an indenter (Shimadzu, HMV-2 Micro Hardness Tester, Shimadzu Corporation, Kyoto, Japan) by the application of a $0.5 \mathrm{Kgf}$ load for $15 \mathrm{~s}$. The test was performed in five samples of each group at four randomly distributed points [32]. The mean was calculated for each sample and then for each group to obtain the hardness (expressed in Vickers hardness units-VHN). The elastic modulus was tested by means of a nano-indenter (TI 950 TriboIndente, Hysitron Inc., Eden Prairie, MN, USA) equipped with a diamond Berkovich-type indenter (100 $\mathrm{nm}$ in diameter). Indentations were performed in at least ten positions of each sample, with a trapezoidal load function with $2 \mathrm{mN}$ of maximum force. The loading, unloading, and dwell times were 5, 5, and $2 \mathrm{~s}$, respectively. The results represent the average among the obtained values [33].

\subsection{Surface characterization}

The chemical composition of the cpTi and $\mathrm{Ti}$ alloys (on the order of $1 \mu^{3}$ ) was checked by energy-dispersive spectroscopy (EDS). X-ray photoelectron spectroscopy (XPS) analysis was used to verify the chemical composition and state of the outermost oxide layer by means of a spectrometer (Vacuum Scientific Workshop, VSW HA100) [34].

Atomic force microscopy (AFM) was used to observe the surface topography of the samples. Images of $50 \times 50 \mu \mathrm{m}$ were obtained by microscope (AFM; 5500 AFM/SPM, Agilent Technologies, Chandler, AZ, USA) from two different areas in the non-contact mode (tapping). Gwyddion software (Gwyddion $\mathrm{v}$ 2.37; GNU General Public License; Czech Republic) was used for image processing [35].

The surface roughness parameters (average roughness, Ra; maximum height of the profile, Rt; average maximum height of the profile, $\mathrm{Rz}$; and root mean square roughness, $\mathrm{Rq}$ ) of the samples were evaluated by profilometry (Dektak 150-d; Veeco, Plainview, NY, USA). The roughness parameters were obtained with a cut-off of $0.25 \mathrm{~mm}$ at $0.05 \mathrm{~mm} / \mathrm{s}$ over $12 \mathrm{~s}$. Three measurements (right, center, and left of the sample) were obtained from five discs of each group and then averaged [32].

Surface free energy was analyzed with a goniometer (Ramé-Hart 100-00; Ramé-Hart Instrument Co., Succasunna, NJ, USA) and the sessile drop method. The water contact angle (polar component) and the diiodomethane contact angle (dispersive component) were calculated with Ramé-Hart DROPimage Standard software (Ramé-Hart Instrument Co., Succasunna, NJ, USA). The polar and dispersive components and the surface free energy were calculated [35].

\subsection{Electrochemical tests}

The corrosion assessment was carried out with a potentiostat (Interface 1000, Gamry Instruments, Warminster, PA, USA) and a standardized method of three-electrode cells as required by ASTM International (formerly the American Society for Test- 
ing and Materials (ASTM)) (G61-86 and G31-72). A saturated calomel electrode (SCE) was used as the reference electrode, a graphite rod as the counterelectrode, and the exposed surface of the sample as the working electrode. The electrolyte solution used was simulated body fluid (SBF) at $37 \pm 1^{\circ} \mathrm{C}(\mathrm{pH} 7.4)$ to mimic blood plasma. In total, a $10-\mathrm{mL}$ quantity of electrolyte was used for each corrosion experiment [24]. The chemical composition of the SBF (in kg/m 3 ) was $\mathrm{NaCl}$ (12.0045), $\mathrm{NaHCO}_{3}$ (0.5025), $\mathrm{KCl}$ (0.3360), $\mathrm{K}_{2} \mathrm{HPO}_{4}$ (0.2610), $\mathrm{Na}_{2} \mathrm{SO}_{4}$ (0.1065), $1 \mathrm{M}$ $\mathrm{HCl}(60 \mathrm{~mL}), \mathrm{CaCl}_{2} \cdot 2 \mathrm{H}_{2} \mathrm{O}(0.5520)$, and $\mathrm{MgCl}_{2} \cdot \mathrm{H}_{2} \mathrm{O}(0.4575)$ [36]. Tris was used to achieve a $\mathrm{pH}=7.4$. The exposed area (in $\mathrm{cm}^{2}$ ) of Ti materials was determined by AFM (cpTi=1.07, Ti$6 \mathrm{Al}-4 \mathrm{~V}=0.99, \mathrm{Ti}-5 \mathrm{Zr}=1.01, \mathrm{Ti}-10 \mathrm{Zr}=1.31, \mathrm{Ti}-35 \mathrm{Nb}-5 \mathrm{Zr}=1.06$, and $\mathrm{Ti}-35 \mathrm{Nb}-10 \mathrm{Zr}=1.03)$.

Electrochemical testing was conducted according to a specific protocol $[24,35]$. A cathodic potential (-0.9 V vs. SCE) was applied for $10 \mathrm{~min}$ to standardize the oxide layers of the samples. The open circuit potential was monitored for a period of $3600 \mathrm{~s}$ to assess the free corrosion potential of the material in the electrolyte solution. For evaluation of the passive layer, electrochemical impedance spectroscopy (EIS) was measured at a frequency of $100 \mathrm{kHz}-5 \mathrm{mHz}$, with the AC curve at a range of $\pm 10 \mathrm{mV}$ applied to the electrode at its corrosion potential. The values were used to determine the real $\left(Z^{\prime}\right)$ and imaginary $\left(Z^{\prime \prime}\right)$ components of impedance, which were used to construct Nyquist, Bode $(|Z|)$, and phase angle plots. The EIS data were analyzed with Echem Analyst software (Gamry Instruments, Warminster, PA, USA). An equivalent electrical circuit was fitted for quantification of the corrosion process in the passive/oxide film formation (polarization resistance, $R_{p}$, and constant phase element, CPE).

The samples were then polarized from -0.8 to $1.8 \mathrm{~V}$ (scan rate of $2 \mathrm{mV} / \mathrm{s}$ ). Corrosion parameters such as $\mathrm{E}_{\mathrm{corr}}$ (corrosion potential), $\mathrm{I}_{\text {corr }}$ (corrosion current density), and Tafel slopes $\left(b_{c}, b_{a}\right)$ were obtained from the potentiodynamic polarization curves by the Tafel extrapolation method (Echem Analyst Software, Gamry Instruments, Warminster, PA, USA). The passivation current density ( $\mathrm{I}_{\text {pass }}$ ) corresponds to the current value of the passivation region of the polarization plot. The percentage corrosion efficiencies with regard to the values of $\mathrm{I}_{\text {corr }}$ (Eq. (1)) and $\mathrm{R}_{\mathrm{p}}$ (Eq. (2)) were calculated:

$\% \mathrm{CE}=\frac{\mathrm{I}_{\mathrm{corr}}{ }^{*}-\mathrm{I}_{\mathrm{corr}}}{\mathrm{I}_{\mathrm{corr}}{ }^{*} \times 100}$

$\% C E=\frac{R_{p}^{*}-R_{p}}{R_{p}^{*} \times 100}$

where $\mathrm{I}_{\text {corr }}{ }^{*}$ and $\mathrm{I}_{\text {corr }}$ are the corrosion current density of $\mathrm{cpTi}$ and the Ti alloys, respectively, and $\mathrm{R}_{\mathrm{p}}{ }^{*}$ and $\mathrm{R}_{\mathrm{p}}$ are the polarization resistance of $\mathrm{cpTi}$ and the Ti alloys, respectively.

The electrochemical tests were conducted at least five times $(n=5)$ to ensure reliability and reproducibility.

\subsection{Protein adsorption}

The protein adsorption assay followed a previous protocol [37]. Briefly, five samples of each group were incubated in $100 \mathrm{mg} / \mathrm{mL}$ of albumin (Sigma-Aldrich, St. Louis, MO, USA) under horizontal stirring $(7.85 \mathrm{rad} / \mathrm{s})$ at $37^{\circ} \mathrm{C}$ for $2 \mathrm{~h}$. Sam-

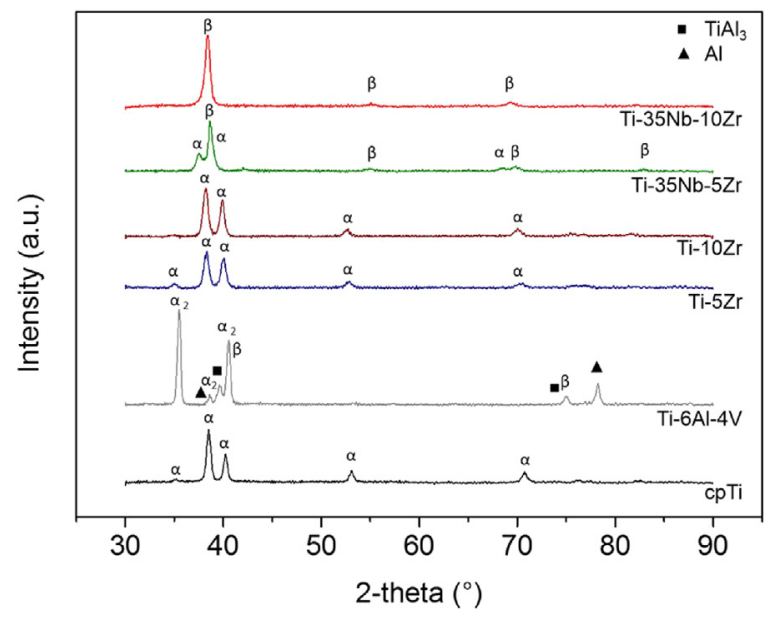

Fig. 2 - X-ray diffraction patterns of cpTi and Ti alloys.

ples were washed in phosphate-buffered saline (PBS) (Gibco, Life Technologies, Gaithersburg, MD, USA) to remove nonadherent proteins, and the protein adsorption was measured by the bicinchoninic acid method (BCA Kit, Sigma-Aldrich, St. Louis, MO, USA).

\subsection{Statistical analyses}

The normality of all response variables was tested by the Shapiro-Wilk method, and data were transformed when necessary. One-way ANOVA was used to test the statistically significant differences among groups with regard to roughness, surface energy, hardness, elastic modulus, electrochemical parameters $\left(\mathrm{R}_{\mathrm{p}}, \mathrm{CPE}, \mathrm{E}_{\mathrm{corr}}, \mathrm{I}_{\mathrm{corr}}\right.$, and $\left.\mathrm{I}_{\text {pass }}\right)$, and protein adsorption. Tukey's HSD test was used as a post hoc technique for multiple comparisons. A mean difference significant at the 0.05 level was used for all tests (SPSS v. 20.0, SPSS Inc.).

\section{Results}

\subsection{Alloy microstructure}

The XRD patterns of the cpTi and Ti alloys are shown in Fig. 2. Only peaks corresponding to the $\alpha$ phase were observed for cpTi and Ti-Zr alloys. The Ti-6Al-4V and Ti-35Nb-5Zr alloys showed a two-phase $(\alpha+\beta)$ structure. Intermetallic peaks of $\mathrm{Al}$ and $\mathrm{TiAl}_{3}$ were detectable for Ti-6Al-4V. In contrast, the Ti-35Nb-10Zr alloy exhibited only a $\beta$ microstructure.

SEM micrographs were obtained after samples were etched with Kroll's solution to confirm the microstructure of the alloys (Fig. 3). Different magnifications are demonstrated among the groups to show the most representative image of the microstructure. Only the grain boundary of the equiaxed $\alpha$ structure was observed for cpTi and Ti-5Zr. Although Ti-10Zr has a composition similar to that of Ti-5Zr, its microstructure was the typical Widmanstätten pattern, containing a fine needle-like structure (acicular $\alpha$ ) with multiple orientations. $\mathrm{Ti}-\mathrm{Nb}-\mathrm{Zr}$ alloys showed a homogenous structure with undefined contours, which made it difficult for their microstructure to be characterized by micrographs. 

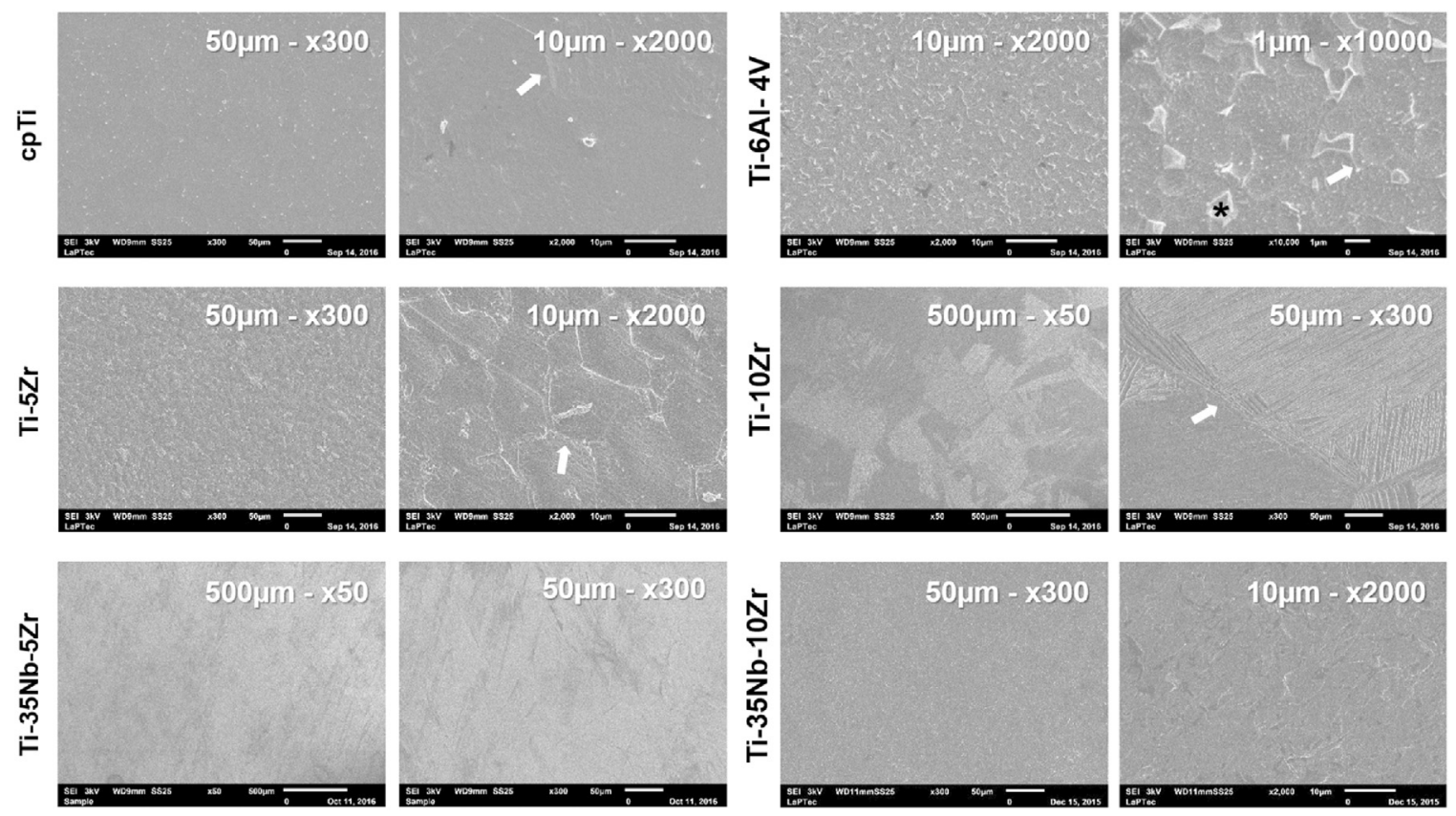

Fig. 3 - SEM micrographs of cpTi and Ti alloys. Arrows indicate the grain boundaries. The asterisk represents the $\beta$ phase of the Ti-6Al-4V alloy.

\subsection{Hardness and elastic modulus}

The hardness and elastic modulus data of cpTi and Ti alloys are shown in Fig. 4. The cpTi hardness was statistically significantly lower than those of all alloys $(p<0.05)$. It can be seen that Ti-Zr alloys had the highest hardness (416-434 VHN), exceeding even that of the Ti-6Al-4V alloy (354 VHN). As expected, Ti-6Al-4V presented the highest elastic modulus, while $\mathrm{Ti}-\mathrm{Nb}-\mathrm{Zr}$ alloys showed statistically significantly lower values $(p<0.05)$.

\subsection{Alloy and oxide layer composition}

The main elements that compose the alloys were determined by EDS and can be observed in the distribution map in Fig. 5. Semi-quantitative analysis of each element (wt\%) is also described. As might be expected, Ti was present in all groups. In addition to the specific elements of each alloy, $C$ and $\mathrm{O}$ were detected in all materials evaluated. A homogeneous distribution of elements can be noted without the presence of aggregations or segregations, indicating that the thermomechanical processing produced a highly homogeneous sample.

Fig. 6 shows the detailed XPS spectrum with the expected compounds for the binding energies detected. The abovementioned alloying elements determined by EDS assessment were also identified as signals by XPS. It can be observed that all bands (Ti2p, O1s, Al2p, Zr3d, Nb3d, and C1s) displayed similar spectral shapes among the groups, with a prevalence of strong peaks of Ti2p, O1s, and C1s (not shown). Regarding the Ti2p, Zr3d, and Nb3d spectral lines, each oxidation state exhibited two peaks (doublets). The calculated relative concentrations of each chemical state in the XPS analysis are described in Table 1.

\subsection{Topography, roughness, and surface free energy}

AFM analysis was performed to extend the information regarding the characterization of the alloys' surface topography. The two- and three-dimensional AFM images are shown in Fig. 7. Similar surfaces were noted among materials, showing longitudinal grooves characteristic of the polishing process. A slight difference was observed for Ti-10Zr and $\mathrm{Ti}-35 \mathrm{Nb}-10 \mathrm{Zr}$ alloys. For the three-dimensional images, these alloys exhibited a decrease in grooves and demonstrated bright regions. Comparative analysis among the surfaces of the alloys took into consideration a standard scale for the Zaxis. The uppermost regions are represented by lighter shades, while the deeper regions are represented by darker shades.

In addition to the qualitative analysis performed by AFM, the surface was quantitatively characterized by profilometry and goniometry. The roughness and surface free energy are shown in Fig. 8. All alloys exhibited $\mathrm{Ra}$ values lower than those of cpTi $(p<0.05)$. Ti-Al-V and Ti-10Zr were the only alloys whose roughness was on the nanometer scale, at 90 and $100 \mathrm{~nm}$, respectively. The $\mathrm{Rq}$ and $\mathrm{Rz}$ results followed a trend similar to that of Ra. Although there was no statistical significance, it can be observed from the Rt measure that $\mathrm{cpTi}$ had deeper valleys and higher peaks, as exhibited by AFM. In contrast, the surface energy values were close to each other among the evaluated materials. Alloys with higher Zr concentration presented statistically significantly lower surface energy than did $\mathrm{cpTi}(\mathrm{p}<0.05)$. No statistically significant difference was found among the experimental groups.

\subsection{Electrochemical assays}

The electrochemical behavior of the experimental alloys in comparison with those of cpTi and Ti-6Al-4V was investigated 

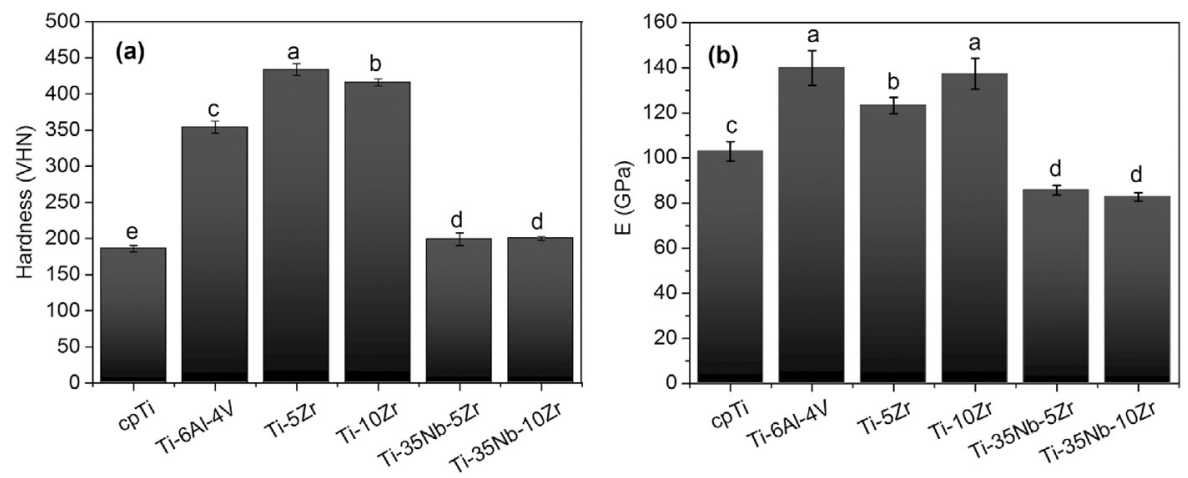

Fig. 4 - (a) Hardness $(n=5)$ and $(b)$ elastic modulus $(E)(n=1)$ of cpTi and Ti alloys. Different letters indicate statistically significant differences among the groups $(p<0.05$, Tukey's HSD test).
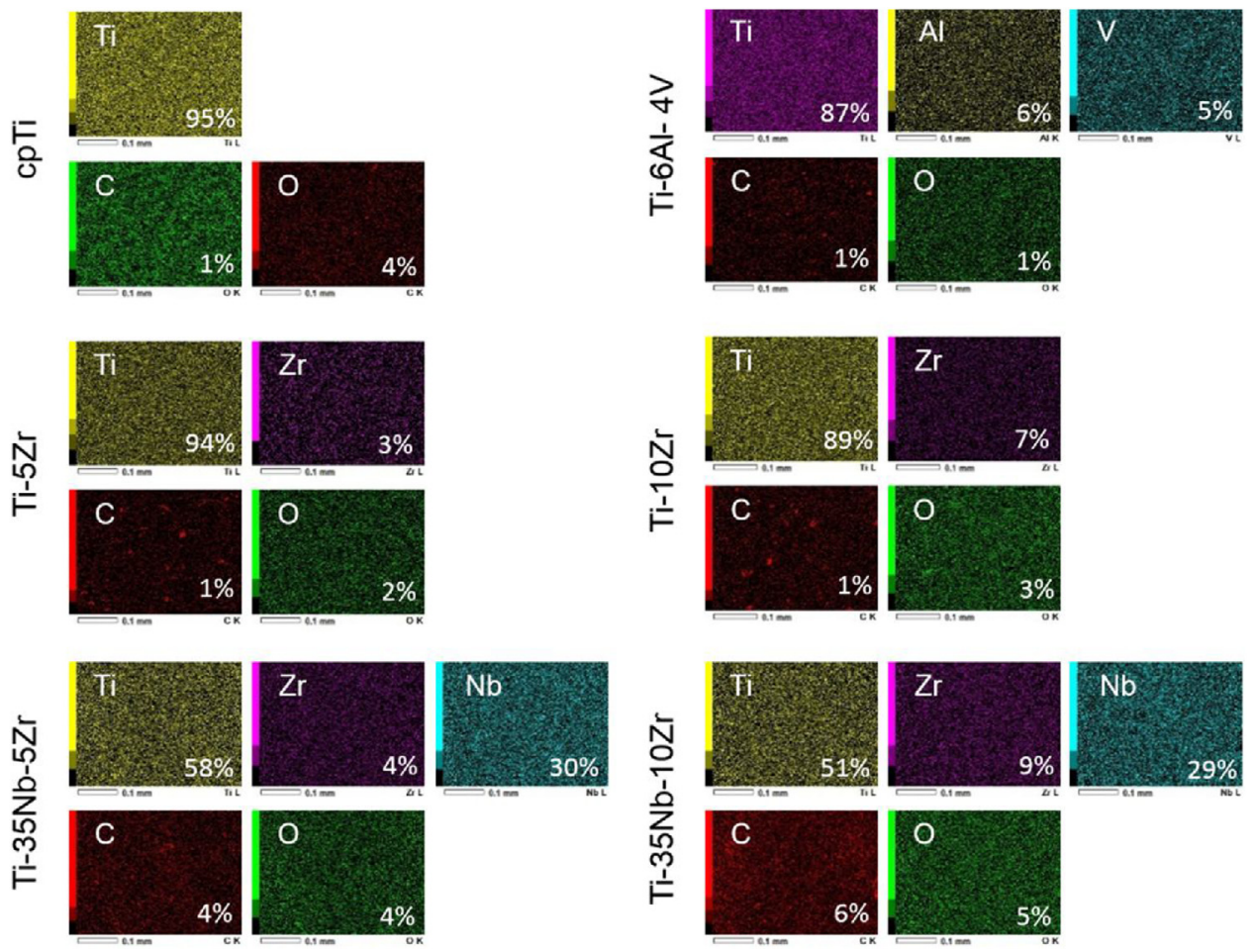

Fig. 5 - Chemical mapping by EDS with element concentrations (wt\%) for cpTi and Ti alloys.

\begin{tabular}{|c|c|c|c|c|c|c|}
\hline \multirow[t]{2}{*}{ Element spectral line } & \multicolumn{6}{|c|}{ Groups } \\
\hline & cpTi (at\%) & Ti-6Al-4V (at\%) & Ti-5Zr (at\%) & Ti-10Zr (at\%) & Ti-35Nb-5Zr (at\%) & Ti-35Nb-10Zr (at\%) \\
\hline Ti2p & 11.4 & 7.0 & 14.0 & 8.6 & 4.3 & 6.5 \\
\hline O1s & 32.4 & 25.5 & 36.7 & 35.4 & 19.6 & 30.3 \\
\hline C1s & 56.2 & 65.0 & 48.7 & 54.8 & 74.1 & 59.6 \\
\hline $\mathrm{V} 3 s+\mathrm{Al} 2 \mathrm{p}$ & - & 2.5 & - & - & - & - \\
\hline Zr3d & - & - & 0.6 & 1.2 & 0.3 & 0.9 \\
\hline Nb3d & - & - & - & - & 1.7 & 2.7 \\
\hline
\end{tabular}

by electrochemical impedance spectroscopy and a potentiodynamic polarization test.

\subsubsection{Electrochemical impedance spectroscopy (EIS)}

Nyquist and Bode plots are shown in Fig. 9. Ti-Zr and Ti-6Al-4V alloys presented higher diameters of the semicircles in the
Nyquist diagram. Regarding the Bode plot, the same alloys presented higher phase angles and increased impedance values at a low frequency range.

The impedance results were modeled with an equivalent electrical circuit and are described in Table 2. A simple electrical circuit consisting of Rsol (polarization resistance of the 

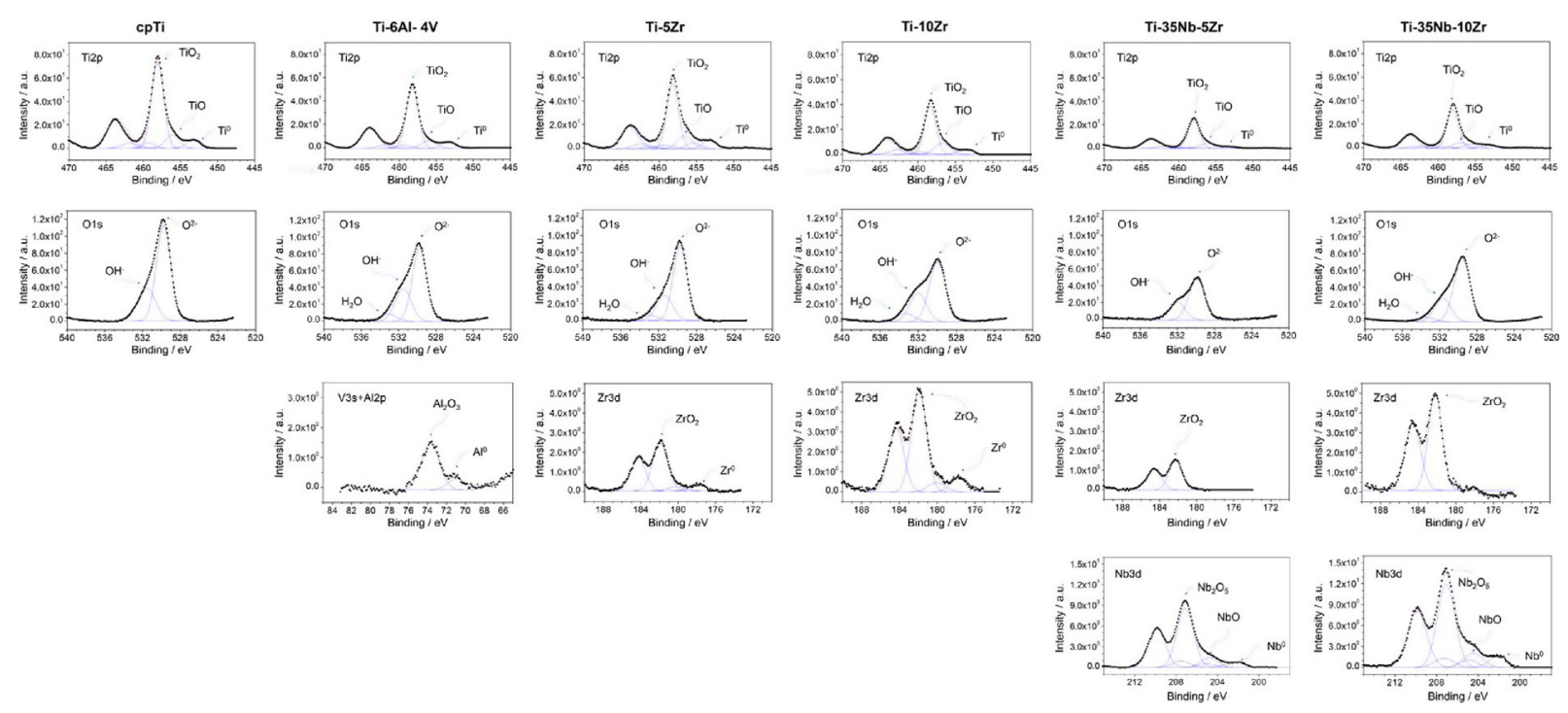

Fig. 6 - Detailed XPS spectra of cpTi and Ti alloys.
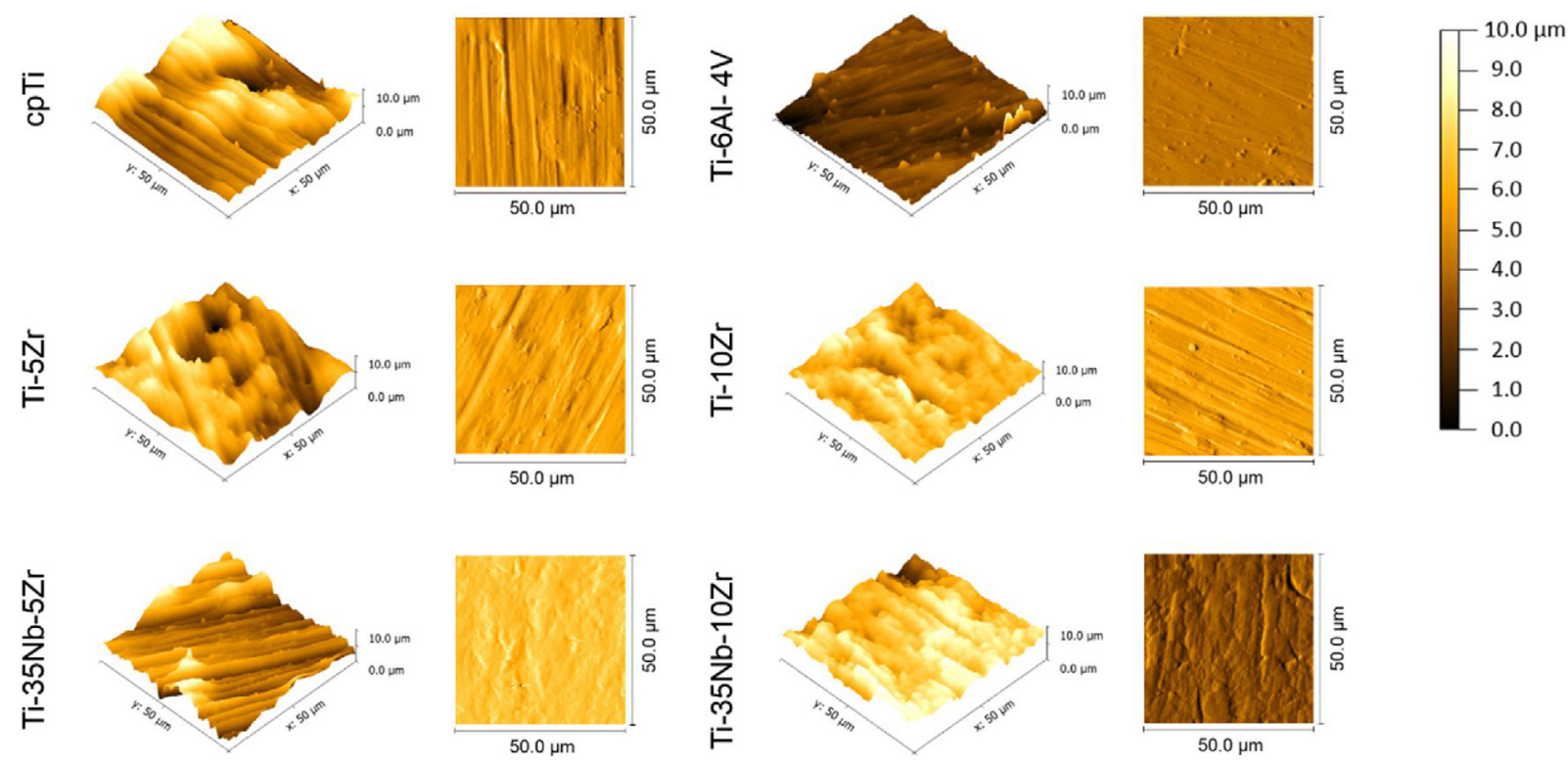

Fig. 7 - Two- and three-dimensional AFM images of cpTi and Ti alloys.
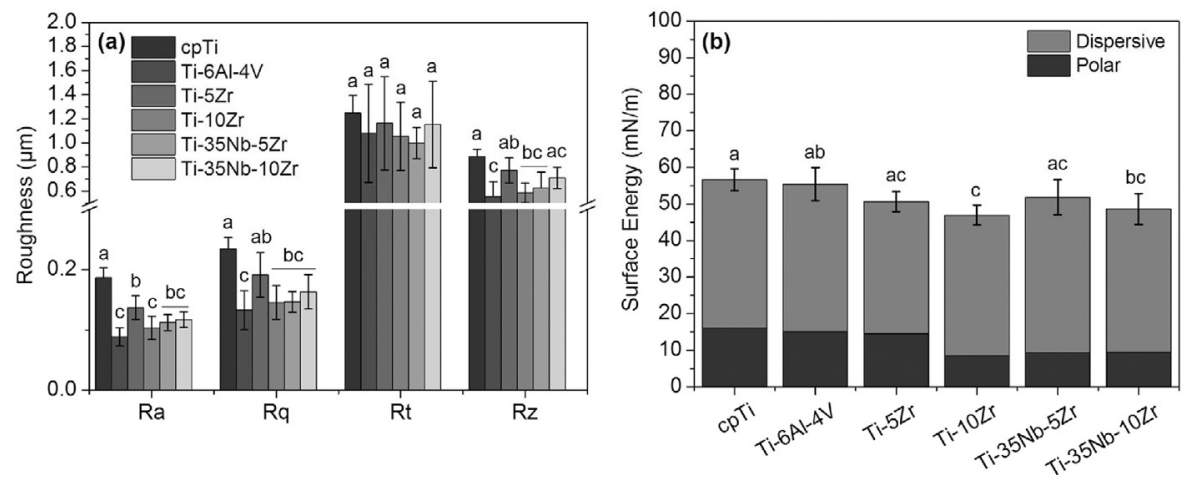

Fig. 8 - (a) Roughness parameters $(n=5)$ and (b) surface energy $(n=5)$ of $c p T i$ and Ti alloys. Different letters indicate statistically significant differences among the groups ( $p<0.05$, Tukey's HSD test). 

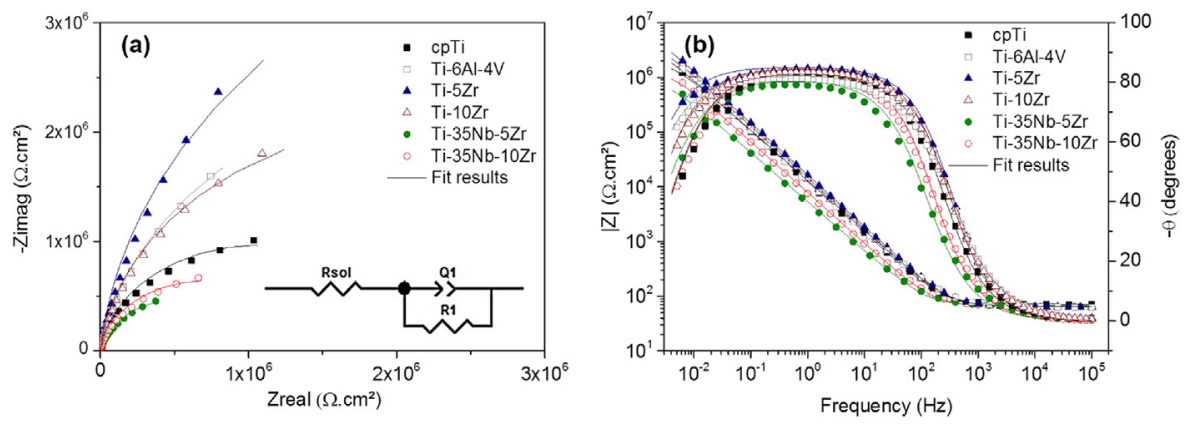

Fig. 9 - Nyquist (a) and Bode (b) diagrams for cpTi and Ti alloys in SBF. The electrical equivalent circuit is shown in the Nyquist diagram. Symbols represent experimental data, and solid lines represent fitted data.

Table 2 - Means and (standard deviations) of electrical parameters obtained from the equivalent circuit models for all groups.

\begin{tabular}{|c|c|c|c|c|c|}
\hline Group & $\mathrm{R}_{\mathrm{p}}\left(\mathrm{M} \Omega \mathrm{cm}^{2}\right)$ & $\mathrm{Q}\left(\mu \Omega^{-1} \mathrm{~s}^{\mathrm{n}} \mathrm{cm}^{-2}\right)$ & $\eta$ & $x^{2} \times 10^{-3}$ & $\mathrm{CE}(\%)^{\mathrm{a}}$ \\
\hline срTi & $2.21(0.51)^{\mathrm{a}}$ & $15.48(1.38)^{\mathrm{a}}$ & $0.92(0.01)$ & $3.18(0.72)$ & - \\
\hline Ti-6Al-4V & $5.56(1.00)^{b}$ & $15.34(1.78)^{\mathrm{a}}$ & $0.91(0.01)$ & $2.17(0.37)$ & 151.58 \\
\hline Ti-5Zr & $9.45(4.48)^{b}$ & $11.36(1.14)^{\mathrm{ab}}$ & $0.93(0.01)$ & $1.89(1.00)$ & 327.60 \\
\hline Ti-10Zr & $7.35(4.54)^{b}$ & $10.83(0.83)^{b}$ & $0.95(0.01)$ & $1.37(0.56)$ & 232.57 \\
\hline $\mathrm{Ti}-35 \mathrm{Nb}-5 \mathrm{Zr}$ & $1.09(0.26)^{\mathrm{c}}$ & $24.31(6.61)^{c}$ & $0.92(0.01)$ & $4.72(1.64)$ & -50.67 \\
\hline Ti-35Nb-10Zr & $1.26(0.39)^{\mathrm{ac}}$ & $25.75(7.60)^{\mathrm{c}}$ & $0.92(0.01)$ & $4.36(2.56)$ & -42.98 \\
\hline
\end{tabular}

Different letters indicate statistically significant differences among the groups ( $p<0.05$, Tukey's HSD test).

${ }^{a}$ Positive values of CE mean an improvement in efficiency, while negative values represent a decrease in efficiency with respect to resistance.

electrolyte), R1 (polarization resistance), and Q1 (constant phase element, CPE) was used (Fig. 9), suggesting a single compact film on the surface. The fitting chi-square evaluation $\left(\chi^{2}\right)$ showed high quality (on the order of $10^{-3}$ ), indicating excellent agreement between the measured and simulated values.

The electrical parameters showed that Ti-Zr and Ti-Al-V exhibited statistically significantly higher resistance than did the other groups $(\mathrm{p}<0.05)$. Ti-35Nb-5Zr demonstrated the worst result, showing a corrosion resistance efficiency that was about $50 \%$ lower in comparison with that of cpTi. In contrast, $\mathrm{Ti}-5 \mathrm{Zr}$ seemed to have more than three times the efficiency of cpTi. Ti-Zr alloys also presented lower capacitance values, while the Ti-Nb-Zr alloys showed slightly

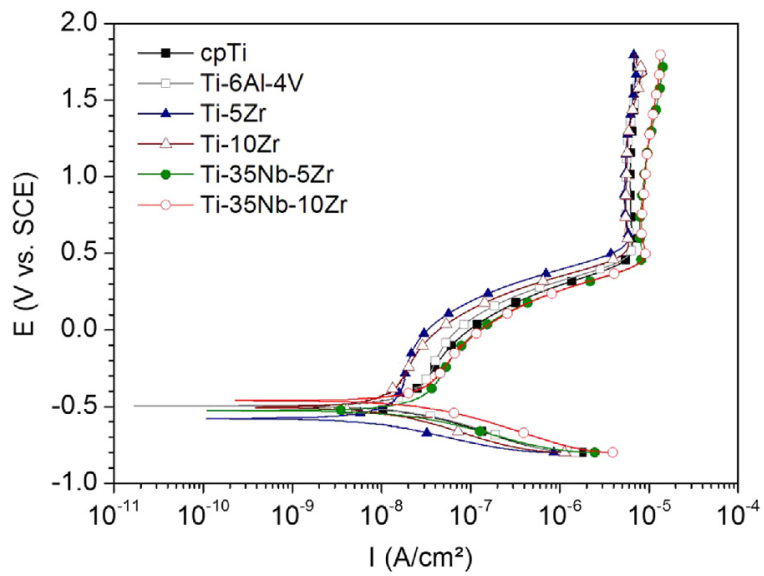

Fig. 10 - Potentiodynamic polarization curves for cpTi and $\mathrm{Ti}$ alloys in SBF. unfavorable values of electrical parameters when compared with those of cpTi.

\subsubsection{Potentiodynamic polarization curves}

The potentiodynamic polarization curves indicated the natural formation of passive oxide layers over all of the sample surfaces (Fig. 10). Ti-Zr alloys presented the most passive feature when compared with the other groups, confirmed by the electronic parameters obtained through Tafel slopes (Table 3). Ti-Zr alloys had a much lower value of corrosion current density $(p<0.05)$ when compared with the control groups and $\mathrm{Ti}-\mathrm{Nb}-\mathrm{Zr}$ alloys. In addition, only Ti-Zr alloys had enhanced corrosion efficiency relative to the $\mathrm{I}_{\text {corr }}$ parameter when compared with the cpTi. Ti-Nb-Zr alloys demonstrated statistically significantly higher current density in the passive region $(p<0.05)$.

\subsection{Albumin adsorption}

We measured the adsorption of albumin for all groups to understand how blood protein interacts with the material surface (Fig. 11). There was no statistically significant difference among the groups $(p=0.184$, one-way ANOVA). However, a slight increase in albumin adsorption could clearly be seen for the alloys with higher amounts of $\mathrm{Zr}$.

\section{Discussion}

\subsection{Microstructural and mechanical properties}

The analysis of the microstructure is important, since several vital characteristics of alloys (i.e., mechanical and corrosion 
Table 3 - Mean and (standard deviation) values of electrochemical parameters obtained from the potentiodynamic polarization curves.

\begin{tabular}{lllllll} 
Group & $E_{\text {corr }}(\mathrm{V}$ vs. SCE $)$ & $I_{\text {corr }}\left(\mathrm{nA} \mathrm{cm}^{-2}\right)$ & $b_{a}\left(\mathrm{mV} \mathrm{dec}^{-1}\right)$ & $-b_{c}\left(\mathrm{mV} \mathrm{dec}^{-1}\right)$ & $\mathrm{I}_{\text {pass }}\left(\mu \mathrm{Acm} \mathrm{cm}^{-2}\right)$ & $\mathrm{CE}(\%)^{\mathrm{a}}$ \\
\hline cpTi & $-0.50(0.02)^{\mathrm{a}}$ & $13.55(3.48)^{\mathrm{ab}}$ & $5.74(0.03)$ & $1.62(0.02)$ & $6.43(0.52)^{\mathrm{a}}$ \\
Ti-6Al-4V & $-0.50(0.06)^{\mathrm{a}}$ & $15.64(3.75)^{\mathrm{ad}}$ & $7.11(0.06)$ & $1.77(0.02)$ & $5.97(0.56)^{\mathrm{a}}$ & 15.42 \\
Ti-5Zr & $-0.51(0.08)^{\mathrm{a}}$ & $8.92(2.27)^{\mathrm{bc}}$ & $7.16(0.14)$ & $1.57(0.04)$ & $6.21(0.51)^{\mathrm{a}}$ & -34.16 \\
Ti-10Zr & $-0.50(0.03)^{\mathrm{a}}$ & $7.17(1.15)^{\mathrm{c}}$ & $6.07(0.04)$ & $1.67(0.02)$ & $5.83(0.39)^{\mathrm{a}}$ & -47.30 \\
Ti-35Nb-5Zr & $-0.51(0.03)^{\mathrm{a}}$ & $25.36(10.83)^{\mathrm{d}}$ & $5.95(0.02)$ & $1.55(0.01)$ & $9.36(1.88)^{\mathrm{b}}$ & 87.15 \\
Ti-35Nb-10Zr & $-0.45(0.04)^{\mathrm{a}}$ & $21.92(3.96)^{\mathrm{ad}}$ & $5.20(0.07)$ & $1.64(0.01)$ & $9.44(2.20)^{\mathrm{b}}$ \\
\hline
\end{tabular}

Different letters indicate statistically significant differences among the groups $(p<0.05$, Tukey's HSD test).

a Positive values of CE mean a decrease in efficiency, while negative values represent an improvement in efficiency with respect to corrosion current density.

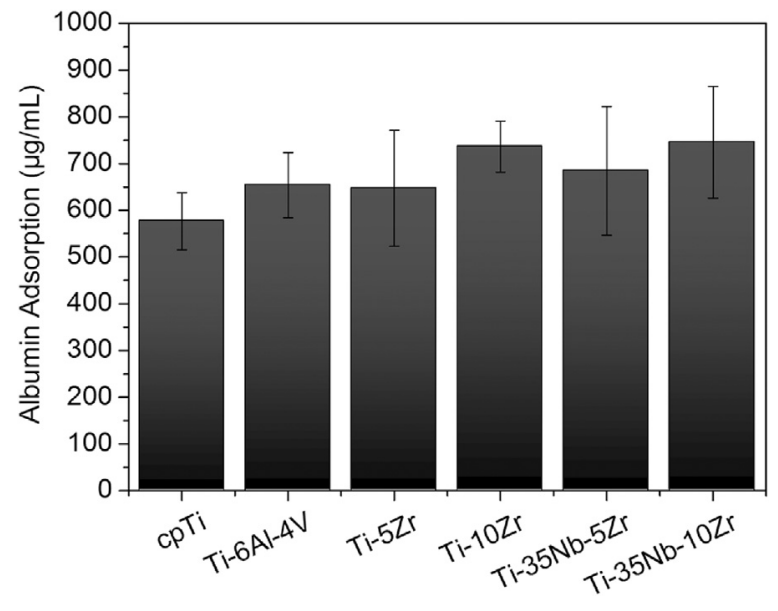

Fig. 11 - Albumin adsorption for cpTi and Ti alloys.

properties) are strongly influenced by microstructural features [38]. The presence of a single phase for the binary alloys showed that Zr, acting as a neutral stabilizer, did not significantly change the crystalline structure of the material [1]. A similar result was described in the literature with Ti-Zr alloys, in which no secondary phase was detected [39]. Further, the Ti-Zr binary system exhibited a completely solid solution for both the high-temperature $\beta$ phase and the low-temperature $\alpha$ phase [40].

Regarding the Ti-6Al-4V alloy, the two-phase structure is due to the presence of $\mathrm{Al}(\alpha$-stabilizer) and $\mathrm{V}$ ( $\beta$-stabilizer) [41]. It exhibited the $\alpha_{2}$ tetragonal structure $\left(\mathrm{Ti}_{3} \mathrm{Al}\right)$ as the main phase as a result of the $\beta \leftrightarrow \alpha \leftrightarrow \alpha_{2}$ transformations. In the micrographs, the presence of the $\beta$ phase (lighter region) dispersed in the contours of the $\alpha$ matrix (darker region) can clearly be seen [42]. Although the Ti-35Nb-5Zr alloy also presented two phases $(\alpha+\beta)$, its microstructure can be considered to be near $\beta$, due to the large amount of the $\beta$ phase stabilizing element [41]. The presence of the $\alpha$ phase in this alloy can be related to the thermomechanical process performed. It has been reported that hot working and solution treatment at temperatures above the $\beta$ transus led to the transformation of part of the $\beta$ phase to the $\alpha$ phase [38]. The samples in this study were air-cooled, which has been demonstrated to be a process that favors the precipitation of the $\alpha$ phase in the $\beta$ matrix [18]. In contrast, the fact that the Ti-35Nb-10Zr alloy contained only the $\beta$ phase can be justified by the higher
$\mathrm{Nb}$ amount and the increased $\mathrm{Zr}$ concentration, which stabilized the $\beta$ phase and inhibited its transformation to the $\alpha$ phase [43]. High concentrations of $\mathrm{Nb}$ have also been revealed to decrease the grain size of $\mathrm{Ti}-\mathrm{xNb}-3 \mathrm{Zr}-2 \mathrm{Ta}$ alloys [44]. It is postulated that such a grain decrease was very significant, so it was difficult to perform the microstructural analysis by SEM. Nevertheless, regions with light and dark colors representative of solute-rich and solute-poor areas, respectively, can be seen [45].

The structural investigation aids in the understanding of the results obtained in the mechanical tests, since both the hardness and the elastic modulus are intrinsically linked to the alloys' microstructural phases. The addition of 5 and $10 \mathrm{wt} \% \mathrm{Zr}$ to Ti was able to more than double the hardness of the alloy. The increase in hardness was mainly caused by the solid-solution strengthening of the $\alpha$-phase [1,39]. Furthermore, the air-cooling process that started from a temperature above the $\beta$ transus can contribute to this property. In this condition, there is the development of a grain refinement of the $\alpha$ phase that was transformed from the $\beta$ phase, which can be the major contributor to hardness [18,38]. A slight decrease in hardness has been reported in the literature with increases in $\mathrm{Zr}$ concentration above $15 \mathrm{wt} \%[1,39]$ and was also verified in our study with a $\mathrm{Zr}$ content of $10 \mathrm{wt} \%$.

The hardness values of ternary Ti-Nb-Zr alloys with 5 and $10 \mathrm{wt} \% \mathrm{Zr}$ were similar. It can be clearly observed that $\mathrm{Nb}$ decreased the alloy hardness to a value close to but statistically significantly greater than that of cpTi. Similarly, a study found higher hardness of $\mathrm{Ti}-\mathrm{Nb}-\mathrm{Zr}$ alloys with greater concentrations of $\mathrm{Zr}$ [46]. The decrease of hardness when compared with that of Ti-Zr alloys demonstrates that the softening behavior of the $\beta$ phase (main phase) seems to have a greater effect on the Ti-35Nb-5Zr alloy than the solid-solution hardening induced by the $\alpha$ phase.

Regarding the elastic modulus, $\mathrm{Ti}-\mathrm{Nb}-\mathrm{Zr}$ alloys deserve attention for presenting the lowest values, closer to those of bone ( $\approx 10-30 \mathrm{GPa}$ ), due to the higher amount of the $\beta$ phase. The $\beta$ phase has a structure (body-centered cubic) that exhibits a lower bonding force among the atoms, which ensures a reduced elastic modulus $[1,47]$ and favorable plastic deformation capacity of the alloy [45]. This result is in agreement with those of other studies that have found a low elastic modulus in $\beta$ ternary alloys containing $\mathrm{Zr}$ and $\mathrm{Nb}$ with different concentrations $[6,23,46,48]$. The combination of high strength and low elastic modulus is expected to minimize the "stress shielding" effect $[23,49]$, which is advantageous in terms of bone atrophy 
inhibition and therefore leads to much better bone remodeling [19] due to improved communication between implant and bone tissue through effective load transfer and uniform stress distribution [49].

In contrast, the studied binary alloys showed an increased elastic modulus, even with a $\mathrm{Zr}$ content of less than $15 \mathrm{wt} \%$, as previously mentioned by Correa et al. [1]. The increased elastic modulus could be related to the heat treatment performed after swaging, which led to the alloy hardening. However, the value for Ti-5Zr was significantly lower than that for the widely used Ti-6Al-4V alloy, which had a higher elastic modulus (139 GPa) due to its hardness behavior. In general, these findings confirm that the mechanical properties are structuresensitive. Therefore, they can be influenced by phase state, precipitate size and distribution, grain and subgrain size, dislocation density, and other factors [50]. Indeed, the mechanical behavior of $\mathrm{Ti}-\mathrm{Nb}-\mathrm{Zr}$ alloys proved to be especially dependent on the quantity of the $\beta$ or $\alpha$ phase.

\subsection{Surface properties}

Surface characteristics such as composition, wettability, and topography influence cell adhesion and proliferation [51,52]. In addition, the biomaterial surface is in direct contact with living tissues, with an immediate effect on the biocompatibility and corrosion process [52]. In this work, the proportions found of the alloying elements showed a small difference from the nominal composition. However, the $\mathrm{Zr}$ and $\mathrm{Nb}$ concentrations were close to stoichiometric values [17], demonstrating greater incorporation during the melting process. This small difference can be attributed to the excluded vibrational contribution to the theoretical formation energy and mixing of unwanted interstitial elements (mainly oxygen) during alloy production [53].

The composition of the oxide layer, assessed by XPS, is shown in Fig. 6. In general, all groups presented a native passive film on a surface formed mainly of $\mathrm{TiO}_{2}$ protective oxide $[16,54,55]$. On the Ti-Al-V alloy, only $\mathrm{Ti}$ and $\mathrm{Al}$ oxides were formed. Normally, $\mathrm{V}$ oxides $\left(\mathrm{V}_{2} \mathrm{O}_{3}\right.$ and $\left.\mathrm{V}_{2} \mathrm{O}_{5}\right)$ can be observed in the oxide layer in extremely small quantities [42], which may hinder their identification. It can be observed that $\mathrm{Zr}$ oxides are present in much lower concentrations than $\mathrm{Ti}$ and $\mathrm{Nb}$ oxides. This is related to the fact that the $\mathrm{Ti}^{4+}$ ions display mobility higher than that of the $\mathrm{Zr}^{4+}$ ions, leading to a significantly reduced amount of $\mathrm{ZrO}_{2}$ oxide at the outermost surface layer [25]. A previous study stated that the uppermost part of the passive layer of $\mathrm{Ti}-\mathrm{Nb}-\mathrm{Zr}$ alloys consists of $\mathrm{TiO}_{2}, \mathrm{Nb}_{2} \mathrm{O}_{5}$, and $\mathrm{ZrO}_{2}$, followed by an intermediate sub-layer containing $\mathrm{Ti}_{2} \mathrm{O}_{3}$, $\mathrm{NbO}_{2}$, and $\mathrm{NbO}$ phases [29]. It can also be observed that the concentration of $\mathrm{Ti}$ oxides decreases with the incorporation of alloying elements; moreover, the presence of $\mathrm{Zr}$ oxides is proportional to its concentration in the alloy.

In all cases, several oxidation states were observed, including weaker contributions of metallic emission coming from the base material $\left(\mathrm{Ti}^{0}, \mathrm{Zr}^{0}, \mathrm{Nb}^{0}\right.$, and $\left.\mathrm{Al}^{0}\right)$ caused due to a sampling depth for XPS similar to that of the oxide layer thickness $[52,54,55]$. These results indicate the formation of a native oxide layer that was not fully oxidized [52]. In addition to the oxides formed with the alloying elements, the 01s binding energies were associated with the formation of three peaks that are representative of $\mathrm{O}^{2-}, \mathrm{OH}$ ions, and adsorbed $\mathrm{H}_{2} \mathrm{O}[16]$. In contrast, the $\mathrm{C} 1 \mathrm{~s}$ band is correlated to carbon contaminants, such as saturated hydrocarbons, $\mathrm{C}-\mathrm{O}$, and $\mathrm{C}-\mathrm{H}$ bonds [55].

The profilometry analysis showed a higher surface roughness for cpTi, corroborating the results from a previous study [51]. The AFM assessment also showed that cpTi, Ti-5Zr, and Ti-35Nb-5Zr have greater variations in height, which can suggest increased roughness. In addition, Ti-6Al-4V and $\mathrm{Ti}-10 \mathrm{Zr}$ alloys demonstrated smoother surfaces in both analyses. The results may be justified by the material properties, such as hardness, which can in some way influence the polishing process. Another driving force toward the roughness parameter is the alloy grain size. The alloys demonstrated micro-features of grain size in the SEM images. Changes in the topography that lead to a rough surface enhance the differentiation of osteoblasts, while a smooth surface increases cell proliferation [65-69]. Surfaces that induce the maturation and proliferation of cells are crucial for improving and accelerating osseointegration [5].

In addition to roughness, biological properties are also influenced by surface free energy. Materials having a higher surface energy show greater wettability, which is important to achieve better cell proliferation and adhesion as well as to absorb more proteins on the surfaces of Ti alloy implants. An important observation of the wettability in this work is the low values of surface energy for the polar component $\left(\mathrm{H}_{2} \mathrm{O}\right)$ in $\mathrm{Ti}-10 \mathrm{Zr}$, Ti-35Nb-5Zr, and Ti-35Nb-10Zr alloys. A less hydrophilic surface can be the main factor generating lower total surface energy values for these alloys.

\subsection{Electrochemical behavior}

The native oxide layer on the Ti surface confers inherent protective corrosion behavior on the implant [2,52] as long as the integrity of the film is maintained [56]. Corrosion resistance is correlated with the lifetime of the implant and the harmfulness of corrosion processes that occur in the body [57]. The improved corrosion resistance found for the binary alloys can be attributed to the fact that $\mathrm{Zr}$ is an anodic alloying element for $\mathrm{Ti}$ that acts to reduce the anodic activity directly [56]. A higher resistance suggests lower corrosion rates, since this parameter is considered a measure of the barrier effect of the passive film against charge transfer [29]. In addition, $\mathrm{Ti}-\mathrm{Zr}$ and $\mathrm{Ti}-6 \mathrm{Al}-4 \mathrm{~V}$ alloys showed the largest diameters on the Nyquist plot, indicating enhanced dielectric properties, namely, an oxide layer that is a better capacitor and is more protective $[16,58,59]$. Similarly, the Bode plot results corroborate the higher protective properties of the alloy's oxide film $[16,25]$.

In contrast, the $\mathrm{Ti}-\mathrm{Nb}-\mathrm{Zr}$ alloy showed the worst behavior as a result of the less resistant passive film on the surface. It can be related to the fact that the $\beta$ phase proved to be less resistant to corrosion than was the $\alpha$ phase [60]. This result differs from those of previous studies of $\mathrm{Ti}-\mathrm{Nb}-\mathrm{Zr}$ alloys, in which similar or even nobler electrochemical behavior was found for the alloys in comparison with cpTi [16] and the Ti-6Al-4V alloy [29]. In these studies, the main reason for the superiority of the alloys was the modification of the passive $\mathrm{TiO}_{2}$ layer by the alloying elements that participate, along with their $\mathrm{ZrO}_{2}$ 
and $\mathrm{Nb}_{2} \mathrm{O}_{5}$ oxides, in the thickening and improved structural integrity of the alloy's native passive film $[16,61,62]$. Although such oxides were detected via XPS, their presence was insufficient to improve the corrosion properties of $\mathrm{Ti}-\mathrm{Nb}-\mathrm{Zr}$ alloys in this study.

A study carried out by Cvijović-Alagić et al. [25] evaluated the corrosion and wear behavior of $\mathrm{Ti}-13 \mathrm{Nb}-13 \mathrm{Zr}$ and Ti-6Al-4V. A better combination of these properties was observed for Ti-6Al-4V. A possible reason for these findings is the greater hardness of the Ti-6Al-4V alloy, which favors the maintenance of a thicker and more firmly adhered oxide layer than does a softer material [25]. Thus, the greater corrosion protection for Ti-Zr alloys in this study can also be justified by their increased hardness, since the solid-solution strengthening of the alloy may be responsible for the enhanced protection against oxidation [39]. Further, alloys with Zr produce significantly more stable anodic oxides, improving the corrosion resistance of the biomaterial [63]. With regard to Ti-6Al-4V, the detected intermetallic compound $\mathrm{TiAl}_{3}$ can also influence the electrochemical behavior of the alloys by having good oxidation resistance [64].

Regarding the polarization curves, the shifts of the curves toward lower current densities (upper left area of the graph) [25] illustrate the improved behavior of Ti-Zr alloys. It can be observed that the current density increased gradually with increases in the potential from the corrosion potential, which can be attributed to the activation polarization [60]. The current density increased until a certain time, when it achieved a constant value ( $\mathrm{I}_{\text {pass }}$ ) of anodic polarization without any active-passive transition [41], indicating the absence of breaks and confirming the thickening of the oxide layer [60].

Confirming the EIS results, the potentiodynamic parameters establish the superior corrosion resistance of Ti-Zr alloys. The lowest $I_{\text {corr }}$ and $I_{\text {pass }}$ values found for these alloys reflect low electrochemical activity and high corrosion resistance properties [16]. A higher $\mathrm{I}_{\text {corr }}$ value is representative of the degree of degradation of the alloy [59]. Lower current density is preferable, since it indicates a more stable and resistant passive film [16,25]. Additionally, there was no statistically significant difference among groups with respect to corrosion potential $\left(\mathrm{E}_{\mathrm{corr}}\right)$, indicating that the corrosion processes below the passive films were similar [25]. A study carried out by Ribeiro et al. [29] with the same Ti-Nb-Zr alloys showed an increase of $E_{c o r r}$ and resistance parameters as a function of the immersion time in artificial saliva, representing decreased reactivity of the alloy and improved efficiency of the corrosion protection of the passive films when in contact with the electrolyte over time.

\subsection{Protein-surface interaction}

Concerning protein adsorption, the alloy chemical composition and the small differences in roughness and surface free energy had no influence on albumin adsorption. The role of small variations of surface roughness $(\mathrm{Ra}<0.50 \mu \mathrm{m})$ in cellular responses and protein adsorption has not been well-defined [51]. However, a previous study found that albumin is adsorbed preferentially onto the smooth Ti-6Al-4V substratum, while the rough substratum binds a higher amount of total serum protein and fibronectin [65].
Composition can also influence protein adsorption. A study that evaluated the addition of boron to the $\mathrm{Ti}-\mathrm{Nb}-\mathrm{Zr}$ alloy showed that the chemical alteration provided by its incorporation was responsible for a decrease in the protein adsorption and cell response [70]. In our study, $\mathrm{Zr}$ and $\mathrm{Nb}$ were not detrimental to protein adsorption. Indeed, it was possible to observe that higher concentrations of $\mathrm{Zr}$ led to an increase in this property.

It is expected that hydrophilic nanotopography can facilitate the penetration of nanoscale proteins. Several surface treatments have been investigated with the aim of modifying surface properties. An electrochemical anodization process was capable of creating a nanoporous surface that significantly enhanced albumin and fibronectin protein adsorption, improving the adhesion, migration, proliferation, and mineralization of human bone marrow mesenchymal stem cells in the Ti-25Nb-25Zr alloy [66]. Further studies are needed to understand how changes in alloy surfaces can influence protein adsorption.

\subsection{Clinical implications, limitations, and future perspectives}

In this study, we attempted to perform a full evaluation of $\mathrm{Ti}$ alloys containing $\mathrm{Zr}$ and $\mathrm{Nb}$ as alternatives to cpTi and Ti-Al-V alloys. In an attempt to address all significant issues, it was observed that the experimental alloys are indeed viable options for the manufacture of dental implants. The enhanced mechanical properties of $\mathrm{Ti}-\mathrm{Zr}$ and $\mathrm{Ti}-\mathrm{Nb}-\mathrm{Zr}$ alloys, such as higher microhardness and lower elastic modulus, may ensure that the dental implant has greater clinical applicability. For example, Ti-Zr alloys may be particularly suitable in situations that require greater strength, such as in rehabilitation involving small-diameter implants. In these cases, cpTi is more susceptible to failure, and the use of Ti-Al-V is indicated. However, as already mentioned, the use of the Ti-Al-V alloy has been avoided due to the toxicity related to the release of $\mathrm{Al}$ and $\mathrm{V}$, but this is not a barrier in the case of the proposed non-toxic alloys.

The native passive surface film of $\mathrm{cpTi}$ can be easily destroyed due to the intrinsic low wear resistance of $\mathrm{Ti}$ [6]. Thus, the improved corrosion behavior observed for $\mathrm{Ti}-\mathrm{Zr}$ alloys could prevent passive film damage by mechanical solicitations, which can provide long-term success of rehabilitation by decreasing both the probability of corrosion in physiologic environments and the probability that osseointegration will be harmed. In addition, the similar responses to protein adsorption among the studied materials lead us to believe that none of the experimental alloys will negatively affect the initial adhesion of cells.

Some limitations can be mentioned due to the intrinsic characteristics of the type of research, such as the validation of the results under in vivo physiological conditions. Therefore, a need for in vitro biocompatibility studies and in vivo randomized controlled trials that consolidate the efficacy and safety of alloys as alternatives to cpTi has been reported [5]. Future research should test the experimental alloys by cell culture analysis and under in vivo conditions with the aim of validating their outstanding properties. Further, the influence of immersion time on the electrochemical stability of such 
alloys is warranted for observation of the possible improvement in the Ti-Nb-Zr alloys' behavior. It may be interesting to perform different heat and surface treatments in an attempt to decrease the elastic modulus of Ti-Zr alloys and to enhance the electrochemical properties of $\mathrm{Ti}-\mathrm{Nb}-\mathrm{Zr}$ alloys.

\section{Conclusions}

According to the results found in this study, the following conclusions can be drawn:

- Ti-Zr and Ti-Nb-Zr alloys exhibited an improved combination of hardness and elastic modulus, respectively;

- Ti alloys presented a roughness and surface energy slightly lower than those of cpTi;

- Ti-Zr alloys exhibited superior electrochemical properties, presenting higher polarization resistance and lower values of $I_{\text {corr }}$, corrosion rate, and capacitance parameters; and

- the experimental alloys exhibited albumin adsorption similar to that of control groups.

\section{Acknowledgments}

This work was supported by the São Paulo State Research Foundation (FAPESP), Brazil (grant numbers 2013/08451-1, 2014/26853-2, 2015/25562-7, and 2016/11470-6). The authors also express their gratitude to Rita Vinhas from the Institute of Physics Gleb Wataghin (UNICAMP) for providing the facilities in which to conduct XPS analysis, to Rafael Parra and Jéssica Gonçalves for their contributions and support in the Plasma Technology Laboratory at Universidade Estadual Paulista (UNESP), and to Elton José de Souza from the Department of Physics and Chemistry at UNESP for the AFM facility.

\section{RE F E R E N C ES}

[1] Correa DRN, Vicente FB, Donato TAG, Arana-Chavez VE, Buzalaf MAR, Grandini CR. The effect of the solute on the structure, selected mechanical properties, and biocompatibility of Ti-Zr system alloys for dental applications. Mater Sci Eng C 2014;34:354-9, http://dx.doi.org/10.1016/j.msec.2013.09.032.

[2] Mishnaevsky Jr L, Levashov E, Valiev RZ, Segurado J, Sabirov I, Enikeev N, et al. Nanostructured titanium-based materials for medical implants: modeling and development. Mater Sci Eng R Rep 2014;81:1-19, http://dx.doi.org/10.1016/j.mser.2014.04.002.

[3] Shemtov-Yona K, Rittel D. On the mechanical integrity of retrieved dental implants. J Mech Behav Biomed Mater 2015;49:290-9, http://dx.doi.org/10.1016/j.jmbbm.2015.05.014.

[4] Geetha M, Singh AK, Asokamani R, Gogia AK. Ti based biomaterials, the ultimate choice for orthopaedic implants-a review. Prog Mater Sci 2009;54:397-425, http://dx.doi.org/10.1016/j.pmatsci.2008.06.004.

[5] Cordeiro JM, Barão VAR. Is there scientific evidence favoring the substitution of commercially pure titanium with titanium alloys for the manufacture of dental implants?
Mater Sci Eng C 2017;71:1201-15,

http://dx.doi.org/10.1016/j.msec.2016.10.025.

[6] Hacisalihoglu I, Samancioglu A, Yildiz F, Purcek G, Alsaran A. Tribocorrosion properties of different type titanium alloys in simulated body fluid. Wear 2015;332-333:679-86, http://dx.doi.org/10.1016/j.wear.2014.12.017.

[7] Catalani S, Stea S, Beraudi A, Gilberti ME, Bordini B, Toni A, et al. Vanadium release in whole blood, serum and urine of patients implanted with a titanium alloy hip prosthesis. Clin Toxicol 2013;51:550-6, http://dx.doi.org/10.3109/15563650.2013.818682.

[8] Kaufman AM, Alabre CI, Rubash HE, Shanbhag AS. Human macrophage response to UHMWPE, TiAlV, CoCr, and alumina particles: analysis of multiple cytokines using protein arrays. J Biomed Mater Res A 2008;84:464-74, http://dx.doi.org/10.1002/jbm.a.31467.

[9] Liu N, Meng J, Wang Z, Zhou G, Shi T, Zhao J. Autophagy mediated TiAl(6)V(4) particle-induced peri-implant osteolysis by promoting expression of TNF-alpha. Biochem Biophys Res Commun 2016;473:133-9, http://dx.doi.org/10.1016/j.bbrc.2016.03.065.

[10] Zaffe D, Bertoldi C, Consolo U. Accumulation of aluminium in lamellar bone after implantation of titanium plates, Ti-6Al-4V screws, hydroxyapatite granules. Biomaterials 2004; $25: 3837-44$ http://dx.doi.org/10.1016/j.biomaterials.2003.10.020.

[11] Okazaki Y, Rao S, Ito Y, Tateishi T. Corrosion resistance, mechanical properties, corrosion fatigue strength and cytocompatibility of new Ti alloys without $\mathrm{Al}$ and $\mathrm{V}$. Biomaterials 1998;19:1197-215, http://dx.doi.org/10.1016/S0142-9612(97)00235-4.

[12] Mjoberg B, Hellquist E, Mallmin H, Lindh U. Aluminum, Alzheimer's disease and bone fragility. Acta Orthop Scand 1997;68:511-4, http://dx.doi.org/10.3109/17453679708999016.

[13] Mirza A, King A, Troakes C, Exley C. Aluminium in brain tissue in familial Alzheimer's disease. J Trace Elem Med Biol 2017;40:30-6, http://dx.doi.org/10.1016/j.jtemb.2016.12.001.

[14] Bayón R, Igartua A, González JJ, Ruiz de Gopegui U. Influence of the carbon content on the corrosion and tribocorrosion performance of Ti-DLC coatings for biomedical alloys. Tribol Int 2015;88:115-25, http://dx.doi.org/10.1016/j.triboint.2015.03.007.

[15] Fojt J, Joska L, Malek J. Corrosion behaviour of porous Ti-39Nb alloy for biomedical applications. Corros Sci 2013;71:78-83, http://dx.doi.org/10.1016/j.corsci.2013.03.007.

[16] Calderon-Moreno JM, Vasilescu C, Drob SI, Ivanescu S, Osiceanu P, Drob P, et al. Microstructural and mechanical properties, surface and electrochemical characterisation of a new Ti-Zr-Nb alloy for implant applications. J Alloys Compd 2014;612:398-410, http://dx.doi.org/10.1016/j.jallcom.2014.05.159.

[17] Kuroda PAB, Buzalaf MAR, Grandini CR. Effect of molybdenum on structure, microstructure and mechanical properties of biomedical Ti-20Zr-Mo alloys. Mater Sci Eng C 2016;67:511-5, http://dx.doi.org/10.1016/j.msec.2016.05.053.

[18] Mohammed MT, Khan ZA, Geetha M, Siddiquee AN. Microstructure, mechanical properties and electrochemical behavior of a novel biomedical titanium alloy subjected to thermo-mechanical processing including aging. J Alloys Compd 2015;634:272-80, http://dx.doi.org/10.1016/j.jallcom.2015.02.095.

[19] Niinomi M, Nakai M, Hieda J. Development of new metallic alloys for biomedical applications. Acta Biomater 2012;8:3888-903, http://dx.doi.org/10.1016/j.actbio.2012.06.037.

[20] Grandin HM, Berner S, Dard M. A review of Titanium Zirconium (TiZr) alloys for use in endosseous dental 
implants. Materials (Basel) 2012;5:1348-60, http://dx.doi.org/10.3390/ma5081348.

[21] Kopova I, Stráský J, Harcuba P, Landa M, Janeček M, Bačákova L. Newly developed Ti-Nb-Zr-Ta-Si-Fe biomedical beta titanium alloys with increased strength and enhanced biocompatibility. Mater Sci Eng C 2016;60:230-8, http://dx.doi.org/10.1016/j.msec.2015.11.043.

[22] Liu Q, Meng Q, Guo S, Zhao X. $\alpha^{\prime}$ type Ti-Nb-Zr alloys with ultra-low Young's modulus and high strength. Prog Nat Sci Mater Int 2013;23:562-5, http://dx.doi.org/10.1016/j.pnsc.2013.11.005.

[23] Meng Q, Guo S, Liu Q, Hu L, Zhao X. A $\beta$-type TiNbZr alloy with low modulus and high strength for biomedical applications. Prog Nat Sci Mater Int 2014;24:157-62, http://dx.doi.org/10.1016/j.pnsc.2014.03.007.

[24] Barao VAR, Mathew MT, Assuncao WG, Yuan JC-C, Wimmer MA, Sukotjo C. Stability of cp-Ti and Ti-6Al-4V alloy for dental implants as a function of saliva $\mathrm{pH}-\mathrm{an}$ electrochemical study. Clin Oral Implants Res 2012;23:1055-62, http://dx.doi.org/10.1111/j.1600-0501.2011.02265.x.

[25] Cvijović-Alagić I, Cvijović Z, Mitrović S, Panić V, Rakin M. Wear and corrosion behaviour of Ti-13Nb-13Zr and Ti-6Al-4V alloys in simulated physiological solution. Corros Sci 2011;53:796-808, http://dx.doi.org/10.1016/j.corsci.2010.11.014.

[26] Yan Y, Chibowski E, Szcześ A. Surface properties of Ti-6Al-4V alloy part I: surface roughness and apparent surface free energy. Mater Sci Eng C 2017;70:207-15, http://dx.doi.org/10.1016/j.msec.2016.08.080.

[27] Shemtov-Yona K, Rittel D. Fatigue failure of dental implants in simulated intraoral media. J Mech Behav Biomed Mater 2016;62:636-44,

http://dx.doi.org/10.1016/j.jmbbm.2016.05.028.

[28] Shah FA, Trobos M, Thomsen P, Palmquist A. Commercially pure titanium (cp-Ti) versus titanium alloy (Ti6Al4V) materials as bone anchored implants-is one truly better than the other? Mater Sci Eng C 2016;62:960-6, http://dx.doi.org/10.1016/j.msec.2016.01.032.

[29] Ribeiro ALR, Hammer P, Vaz LG, Rocha LA. Are new TiNbZr alloys potential substitutes of the Ti6Al4V alloy for dental applications? An electrochemical corrosion study. Biomed Mater 2013;8:65005, http://dx.doi.org/10.1088/1748-6041/8/6/065005.

[30] Ribeiro ALR, Junior RC, Cardoso FF, Filho RBF, Vaz LG. Mechanical, physical, and chemical characterization of Ti-35Nb-5Zr and Ti-35Nb-10Zr casting alloys. J Mater Sci Mater Med 2009;20:1629-36, http://dx.doi.org/10.1007/s10856-009-3737-x.

[31] Choi M, Hong E, So J, Song S, Kim B-S, Yamamoto A, et al. Tribological properties of biocompatible Ti-10W and Ti-7.5TiC-7.5W. J Mech Behav Biomed Mater 2014;30:214-22, http://dx.doi.org/10.1016/j.jmbbm.2013.11.014.

[32] Faverani LP, Assunção WG, Carvalho de PSP, Yuan JC-C, Sukotjo C, Mathew MT, et al. Effects of dextrose and lipopolysaccharide on the corrosion behavior of a Ti-6Al-4V alloy with a smooth surface or treated with double-acid-etching. PLoS One 2014:9, http://dx.doi.org/10.1371/journal.pone.0093377.

[33] Gordin D, Busardo D, Cimpean A, Vasilescu C, Höche D, Drob $\mathrm{S}$, et al. Design of a nitrogen-implanted titanium-based superelastic alloy with optimized properties for biomedical applications. Mater Sci Eng C 2013;33:4173-82, http://dx.doi.org/10.1016/j.msec.2013.06.008.

[34] Cavalcanti IMG, Ricomini Filho AP, Lucena-Ferreira SC, Da Silva WJ, Paes Leme AF, Senna PM, et al. Salivary pellicle composition and multispecies biofilm developed on titanium nitrided by cold plasma. Arch Oral Biol
2014;59:695-703,

http://dx.doi.org/10.1016/j.archoralbio.2014.04.001.

[35] Marques I da SV, Barao VAR, da Cruz NC, Yuan JC-C, Mesquita MF, Ricomini-Filho AP, et al. Electrochemical behavior of bioactive coatings on $\mathrm{cp}$-Ti surface for dental application. Corros Sci 2015;100:133-46, http://dx.doi.org/10.1016/j.corsci.2015.07.019.

[36] Muller L, Muller FA. Preparation of SBF with different HCO3-content and its influence on the composition of biomimetic apatites. Acta Biomater 2006;2:181-9, http://dx.doi.org/10.1016/j.actbio.2005.11.001.

[37] Beline T, Marques I da SV, Matos AO, Ogawa ES, Ricomini-Filho AP, Rangel EC, et al. Production of a biofunctional titanium surface using plasma electrolytic oxidation and glow-discharge plasma for biomedical applications. Biointerphases 2016;11:11013, http://dx.doi.org/10.1116/1.4944061.

[38] Mohammed MT, Khan ZA, Geetha M, Siddiquee AN Influence of thermo-mechanical processing on microstructure, mechanical properties and corrosion behavior of a new metastable $\beta$-titanium biomedical alloy. Int J Nanomed 2015;38:247-58, http://dx.doi.org/10.2147/IJN.S80000.

[39] Han M-K, Hwang M-J, Yang M-S, Yang H-S, Song H-J, Park Y-J. Effect of zirconium content on the microstructure, physical properties and corrosion behavior of Ti alloys. Mater Sci Eng A 2014;616:268-74, http://dx.doi.org/10.1016/j.msea.2014.08.010.

[40] Wang P, Feng Y, Liu F, Wu L, Guan S. Microstructure and mechanical properties of Ti-Zr-Cr biomedical alloys. Mater Sci Eng C 2015;51:148-52, http://dx.doi.org/10.1016/j.msec.2015.02.028.

[41] Shukla AK, Balasubramaniam R. Effect of surface treatment on electrochemical behavior of CP Ti, Ti-6Al-4V and Ti-13Nb-13Zr alloys in simulated human body fluid. Corros Sci 2006;48:1696-720, http://dx.doi.org/10.1016/j.corsci.2005.06.003.

[42] Krawiec H, Vignal V, Loch J, Erazmus-Vignal P. Influence of plastic deformation on the microstructure and corrosion behaviour of Ti-10Mo-4Zr and Ti-6Al-4V alloys in the Ringer's solution at $37^{\circ} \mathrm{C}$. Corros Sci 2015;96:160-70, http://dx.doi.org/10.1016/j.corsci.2015.04.006.

[43] Rao X, Chu CL, Zheng YY. Phase composition, microstructure, and mechanical properties of porous Ti-Nb-Zr alloys prepared by a two-step foaming powder metallurgy method. J Mech Behav Biomed Mater 2014;34:27-36, http://dx.doi.org/10.1016/j.jmbbm.2014.02.001.

[44] Rao X, Chu CL, Zheng YY. Phase composition, microstructure, and mechanical properties of porous Ti-Nb-Zr alloys prepared by a two-step foaming powder metallurgy method. J Mech Behav Biomed Mater 2014;34:27-36, http://dx.doi.org/10.1016/j.jmbbm.2014.02.001.

[45] Liang SX, Feng XJ, Yin LX, Liu XY, Ma MZ, Liu RP. Development of a new beta Ti alloy with low modulus and favorable plasticity for implant material. Mater Sci Eng C Mater Biol Appl 2016;61:338-43, http://dx.doi.org/10.1016/j.msec.2015.12.076.

[46] Ozan S, Lin J, Li Y, Ipek R, Wen C. Development of Ti-Nb-Zr alloys with high elastic admissible strain for temporary orthopedic devices. Acta Biomater 2015;20:176-87, http://dx.doi.org/10.1016/j.actbio.2015.03.023.

[47] Song Y, Xu DS, Yang R, Li D, Wu WT, Guo ZX. Theoretical study of the effects of alloying elements on the strength and modulus of $\beta$-type bio-titanium alloys. Mater Sci Eng A 1999;260:269-74, http://dx.doi.org/10.1016/s0921-5093(98)00886-7. 
[48] You L, Song X. First principles study of low Young's modulus Ti-Nb-Zr alloy system. Mater Lett 2012;80:165-7, http://dx.doi.org/10.1016/j.matlet.2012.01.145.

[49] Nune KC, Misra RDK, Li SJ, Hao YL, Yang R. Osteoblast cellular activity on low elastic modulus Ti-24Nb-4Zr-8Sn alloy. Dent Mater 2017;33:152-65, http://dx.doi.org/10.1016/j.dental.2016.11.005.

[50] Brailovski V, Prokoshkin S, Gauthier M, Inaekyan K, Dubinskiy S, Petrzhik M, et al. Bulk and porous metastable beta $\mathrm{Ti}-\mathrm{Nb}-\mathrm{Zr}(\mathrm{Ta})$ alloys for biomedical applications. Mater Sci Eng C 2011;31:643-57, http://dx.doi.org/10.1016/j.msec.2010.12.008.

[51] Sista S, Wen C, Hodgson PD, Pande G. The influence of surface energy of titanium-zirconium alloy on osteoblast cell functions in vitro. J Biomed Mater Res A 2011;97:27-36, http://dx.doi.org/10.1002/jbm.a.33013.

[52] López MF, Jiménez JA, Gutiérrez A. XPS characterization of surface modified titanium alloys for use as biomaterials. Vacuum 2011;85:1076-9, http://dx.doi.org/10.1016/j.vacuum.2011.03.006.

[53] Karre R, Niranjan MK, Dey SR. First principles theoretical investigations of low Young's modulus beta Ti-Nb and $\mathrm{Ti}-\mathrm{Nb}-\mathrm{Zr}$ alloys compositions for biomedical applications. Mater Sci Eng C 2015;50:52-8,

http://dx.doi.org/10.1016/j.msec.2015.01.061.

[54] Stenlund P, Omar O, Brohede U, Norgren S, Norlindh B. Bone response to a novel Ti-Ta-Nb-Zr alloy. Acta Biomater 2015;20:165-75, http://dx.doi.org/10.1016/j.actbio.2015.03.038.

[55] Liu YZ, Zu XT, Li C, Qiu SY, Huang XQ Wang LM. Surface characteristics and corrosion behavior of Ti-Al-Zr alloy implanted with Al and Nb. Corros Sci 2007;49:1069-80, http://dx.doi.org/10.1016/j.corsci.2006.06.028.

[56] Wang ZB, Hu HX, Zheng YG, Ke W, Qiao YX. Comparison of the corrosion behavior of pure titanium and its alloys in fluoride-containing sulfuric acid. Corros Sci 2016;103:50-65, http://dx.doi.org/10.1016/j.corsci.2015.11.003.

[57] Ramírez G, Rodil SE, Arzate H, Muhl S, Olaya JJ. Niobium based coatings for dental implants. Appl Surf Sci 2011;257:2555-9, http://dx.doi.org/10.1016/j.apsusc.2010.10.021

[58] Vasilescu C, Drob SI, Neacsu EI, Mirza Rosca JC. Surface analysis and corrosion resistance of a new titanium base alloy in simulated body fluids. Corros Sci 2012;65:431-40, http://dx.doi.org/10.1016/j.corsci.2012.08.042.

[59] Oláh N, Fogarassy Z, Furkó M, Balázsi C, Balázsi K. Sputtered nanocrystalline ceramic TiC/amorphous $C$ thin films as potential materials for medical applications. Ceram Int 2015;41:5863-71, http://dx.doi.org/10.1016/j.ceramint.2015.01.017.
[60] Yang Y, Xia C, Feng Z, Jiang X, Pan B, Zhang X, et al. Corrosion and passivation of annealed Ti-20Zr-6.5Al-4V alloy. Corros Sci 2015;101:56-65, http://dx.doi.org/10.1016/j.corsci.2015.08.038.

[61] Gabriel SB, Panaino JVP, Santos ID, Araujo LS, Mei PR, de Almeida LH, et al. Characterization of a new beta titanium alloy, Ti-12Mo-3Nb, for biomedical applications. J Alloys Compd 2012;536(Suppl. 1):S208-10, http://dx.doi.org/10.1016/j.jallcom.2011.11.035.

[62] Yu SY, Scully JR. Corrosion and passivity of Ti-13\% Nb-13\% Zr in comparison to other biomedical implant alloys. Corrosion 1997;53:965-76, http://dx.doi.org/10.5006/1.3290281.

[63] Ferreira EA, Rocha-Filho RC, Biaggio SR, Bocchi N. Corrosion resistance of the Ti-50Zr at.\% alloy after anodization in different acidic electrolytes. Corros Sci 2010;52:4058-63, http://dx.doi.org/10.1016/j.corsci.2010.08.021.

[64] Luo Q, Li Q, Jin F, Zhang J-Y, Yu X-B, Gu Q-F, et al. The crystal structure, microhardness and thermal stability of the Ti26Al55Zn19 alloy. Intermetallics 2012;26:136-41, http://dx.doi.org/10.1016/j.intermet.2012.02.020.

[65] Deligianni DD, Katsala N, Ladas S, Sotiropoulou D, Amedee J, Missirlis YF. Effect of surface roughness of the titanium alloy Ti-6Al-4V on human bone marrow cell response and on protein adsorption. Biomaterials 2001;22:1241-51, http://dx.doi.org/10.1016/s0142-9612(00)00274-x.

[66] Huang H, Wu C, Sun Y, Yang W, Lin M, Lee T. Surface nanoporosity of $\beta$-type Ti-25Nb-25Zr alloy for the enhancement of protein adsorption and cell response. Surf Coat Technol 2014;259:206-12, http://dx.doi.org/10.1016/j.surfcoat.2014.02.037.

[67] Sun Y, Liu J, Wu C, Huang H. Nanoporous surface topography enhances bone cell differentiation on Ti-6Al-7Nb alloy in bone implant applications. J Alloys Compd 2015;643:124-32, http://dx.doi.org/10.1016/j.jallcom.2015.01.019.

[68] Kaluderovic MR, Mojic M, Schreckenbach JP, Maksimovic-Ivanic D, Graf H-L, Mijatovic S. A key role of autophagy in osteoblast differentiation on titanium-based dental implants. Cells Tissues Organs 2014;200:265-77, http://dx.doi.org/10.1159/000434625.

[69] Oliveira DP, Palmieri A, Carinci F, Bolfarini C. Gene expression of human osteoblasts cells on chemically treated surfaces of Ti-6Al-4V-ELI. Mater Sci Eng C 2015;51:248-55, http://dx.doi.org/10.1016/j.msec.2015.03.011.

[70] Majumdar P, Singh SB, Dhara S, Chakraborty M. Influence of boron addition to Ti-13Zr-13Nb alloy on MG63 osteoblast cell viability and protein adsorption. Mater Sci Eng C 2015;46:62-8, http://dx.doi.org/10.1016/j.msec.2014.10.012. 